\title{
Z J J \\ Perbandingan Leksikon Bahasa Jawa Dialek Malang dan Bahasa Jawa Dialek Blitar
}

\author{
Pradicta Nurhuda ${ }^{1}$; Zainal Rafli²; Siti Ansoriyah ${ }^{3}$ \\ 1,2,3 Program Magister Linguistik Terapan, Pascasarjana Universitas Negeri Jakarta
}

Posel: dictacutel0@gmail.com

\begin{abstract}
Abstrak: Penelitian ini bertujuan untuk mengetahui perbandingan leksikon bahasa Jawa dialek Malang dan bahasa Jawa Dialek Blitar berdasarkan bentuk dan makna kedua bahasa tersebut. Penelitian ini merupakan jenis penelitian deskriptif dengan pendekatan kualitatif. Data dalam penelitian ini berupa leksikon yang terdapat dalam tuturan masyarakat bahasa Jawa dialek Malang dan masyarakat bahasa Jawa dialek Blitar. Pengumpulan data dalam penelitian ini menggunakan metode simak dengan teknik dasar berupa teknik simak, libat, dan cakap yang dilanjutkan dengan teknik cakap secara virtual dan teknik catat. Metode yang digunakan adalah metode agih dan padan. Analisis data yang digunakan adalah metode padan dengan teknik menyesuaikan dengan karakter data yang diperoleh dan tujuan penelitian, yaitu teknik pilah unsur penentu sebagai teknik dasar. Hasil penelitian ini menunjukkan bahwa (1) terdapat leksikon yang memiliki bentuk berbeda, tetapi maknanya sama pada bahasa Jawa dialek Malang (BJM) dan bahasa Jawa Dialek Blitar (BJB); (2) terdapat leksikon yang memiliki bentuk mirip dan makna yang sama pada bahasa Jawa dialek Malang (BJM) dan bahasa Jawa Dialek Blitar (BJB); dan (3) terdapat leksikon yang memiliki bentuk sama, tetapi maknanya berbeda pada bahasa Jawa dialek Malang (BJM) dan bahasa Jawa Dialek Blitar (BJB).
\end{abstract}

Kata-kata kunci: perbandingan leksikon, bahasa Jawa, dialek Malang, dialek Blitar

Abstract. This study aims to compare the Javanese lexicon Malang dialect and the Blitar dialect based on the forms and meanings of the two languages. This research is a descriptive research with a qualitative approach. The data in this study are in the form of lexicons contained in the speech of the Javanese language community in the Malang dialect and the Javanese language community in the Blitar dialect. Collecting data in this study using the observation method with basic techniques in the form of listening, engaging, and proficient techniques followed by virtual proficient techniques and note-taking techniques. The method used is the agih and matching method. The data analysis used is the equivalent method with the technique of adapting to the character of the data obtained and the research objectives, namely the technique of sorting the determining elements as a basic technique. The results of this study indicate that (1) there is a lexicon that has the different form and meaning in the Javanese Malang dialect (BJM) and the Javanese Blitar dialect (BJB); (2) there is a lexicon which has a similar shape and meaning in the Javanese Malang dialect (BJM) and the Javanese Blitar dialect (BJB); and (3) there is a lexicon which has the same shape, while the meaning is different in the Javanese Malang dialect (BJM) and the Javanese Blitar dialect (BJB).

Keywords: comparison of lexicons, Javanese language, Malang dialect, Blitar dialect

\section{PENDAHULUAN}

Sebagai makhluk sosial manusia tidak bisa lepas dari bahasa. Bahasa sangat menentukan terjalinnya komunikasi masyarakat dalam kehidupan sehari-hari serta dalam bersosialisasi antarsesama. Oleh karena itu, salah satu hal yang tidak dapat dipisahkan dari kehidupan manusia adalah bahasa. Melalui bahasa, manusia dapat menyampaikan informasi atau harapannya kepada orang lain. Widjono (2007) menyatakan bahwa bahasa merupakan asas yang dipakai dalam berkomunikasi oleh masyarakat dalam bentuk simbol bunyi ujaran.

Masyarakat mempunyai banyak ragam bahasa dalam berkomunikasi. Jika di kotakota besar banyak masyarakat menggunakan bahasa Indonesia dalam berkomunikasi, lain 
halnya di desa-desa atau bahkan beberapa kota yang masih menggunakan bahasa daerah. Ragam bahasa daerah di Indonesia sangat banyak, yaitu berjumlah 718 bahasa daerah (tidak termasuk dialek dan subdialek) (Bahasa Dan Peta Bahasa Di Indonesia, 2019). Salah satu ragam bahasa daerah yang memiliki jumlah pemakai terbesar di Indonesia adalah bahasa Jawa. Pemakai bahasa Jawa sebagian besar berada di pulau Jawa, tetapi beberapa pemakai menyebar di semua pulau di Indonesia karena adanya perpindahan penduduk atau migrasi. Menurut Zulaeha (2010), bahasa Jawa dipakai sebagai bahasa Ibu oleh suku Jawa yang menempati Provinsi Jawa Tengah, Daerah Istimewa Yogyakarta (DIY), dan Jawa Timur. Dalam penggunaan bahasa Jawa di masing-masing wilayah tersebut, terdapat berbagai variasi bahasa yang khas atau disebut dengan dialek.

Dialek adalah variasi bahasa yang berbeda-beda menurut pemakai (misalnya bahasa dari suatu daerah tertentu, kelompok sosial tertentu, atau kurun waktu tertentu) (Kamus, 2016). Weijnen dalam Ayatrohaedi (2002) menyatakan bahwa dialek adalah sistem kebahasaan yang dipakai oleh suatu masyarakat untuk membedakan dari masyarakat lain yang berdekatan atau pemakaian sistem yang berlainan walaupun memiliki hubungan yang erat. Berdasarkan pengertian di atas bahwa dialek merupakan sistem kebahasaan yang digunakan masyarakat untuk membedakan dari masyarakat lain yang berdekatan, bahasa Jawa di Jawa Timur memiliki empat dialek, yaitu dialek Jawa Timur, dialek Osing, dialek Tengger, dan dialek Solo-Yogya (Bahasa Jawa Provinsi Jawa Timur, n.d.). Berdasarkan letak geografis, Kabupaten Malang berbatasan langsung dengan Kabupaten Blitar. Walaupun bertetangga secara geografis, dua kabupaten ini memiliki dialek yang berbeda. Jika Malang menggunakan dialek Jawa Timur, Blitar menggunakan dialek Solo-Yogya.

Jika dilihat dalam peta Jawa Timur, Kabupaten Malang berada di sisi sebelah timur, sedangkan Kabupaten Blitar berada di sebelah barat. Dari dialek yang dipakai di wilayah Blitar (Kabupaten dan Kota Blitar) dan di wilayah Malang (Kabupaten dan Kota Malang), terdapat perbedaan yang tampak jelas dari kedua dialek tersebut. Bahasa Jawa yang digunakan di wilayah Malang terkenal khas menggunakan bahasa Jawa ngoko khas Jawa Timur cenderung kasar, sedangkan bahasa Jawa yang digunakan di wilayah Blitar menggunakan di bahasa Jawa ngoko khas Solo-Yogya yang cenderung halus. Dari segi watak, masyarakat dari kedua wilayah ini (Malang dan Blitar) juga memiliki perbedaan. Masyarakat di wilayah Malang memiliki watak yang terbuka, terus terang, dan tidak suka basa-basi. Sementara itu, masyarakat di wilayah Blitar memiliki watak yang agak tertutup dan masih suka basa-basi dalam berkomunikasi dengan tujuan lawan bicaranya tidak tersinggung serta masih menjunjung kesopanan yang tinggi dalam berbicara dengan orang yang golongan atau usianya berbeda.

Ciri khas dari bahasa Jawa dialek Malang adalah intonasi yang disampaikan oleh pembicara terkesan keras dan kasar. Sementara itu, ciri khas dari bahasa Jawa dialek Blitar adalah intonasi yang disampaikan oleh pembicara lebih kalem dan halus. Secara umum bahasa Jawa dialek Malang menggunakan dialek Jawa Timur, tetapi di kalangan beberapa masyarakat Malang terdapat bahasa yang dibalik (bahasa walikan) dari huruf akhir ke huruf awal atau suku kata akhir ke suku kata awal, misalnya arek menjadi kera, Malang menjadi Ngalam, dan monyet menjadi tenyom. Bahasa Jawa dialek Blitar karena menggunakan dialek Solo-Yogya dapat dilihat dari intonasi pembicara yang terkesan halus dengan menerapkan unggah-ungguh terhadap status atau usia lawan bicara.

Walaupun ada beberapa kosakata bahasa Jawa dialek Malang dan bahasa Jawa dialek Blitar yang berbeda, ada beberapa kosakata yang memiliki kesamaan. Dalam penelitian ini peneliti ingin mengkaji lebih dalam beberapa kosakata bahasa Jawa dialek Malang dan bahasa Jawa dialek Blitar yang memiliki persamaan dan perbedaan bentuk. Oleh karena itu, peneliti merumuskan masalah dalam penelitian ini menjadi tiga rumusan masalah, yaitu (l) bagaimana bentuk leksikon yang memiliki bentuk berbeda, tetapi maknanya sama pada bahasa Jawa dialek Malang (BJM) dan bahasa Jawa Dialek Blitar (BJB); (2) bagaimana bentuk leksikon yang memiliki bentuk mirip dan makna yang sama pada bahasa Jawa dialek Malang (BJM) dan bahasa Jawa Dialek Blitar (BJB); dan (3) bagaimana bentuk leksikon yang memiliki bentuk sama, tetapi maknanya berbeda pada bahasa Jawa dialek Malang (BJM) dan bahasa Jawa Dialek Blitar (BJB). 


\section{LANDASAN TEORI}

Penelitian yang telah dilakukan sebelumnya yang relevan dengan penelitian ini adalah sebagai berikut. (1) Penelitian yang dilakukan Afandi (2010) berjudul Perbandingan Leksikon Bahasa Jawa Cirebon dengan bahasa Jawa Standar. Hasil penelitian menunjukkan bahwa leksikon bahasa Jawa Cirebon dan Bahasa Jawa standar memiliki bentuk yang sama, tetapi memiliki makna yang berbeda, yaitu pada kelas verba dan nomina. (2) Penelitian yang dilakukan Adha (2011) berjudul Bahasa Jawa Dialek Gresik: Kajian Morfofonemik. Hasil penelitian menunjukkan bahwa variasi dialek bahasa Jawa masyarakat Gresik Jawa melalui aspek morfofonemik. Selain itu, hasil penelitian ini menunjukkan gejala perubahan dan penghilangan fonem. (3) Penelitian yang dilakukan Widayani (2015) berjudul Variasi Dialek Bahasa Jawa di Wilayah Kabupaten Lamongan: Kajian Dialek Geografis. Hasil penelitian menunjukkan bahwa terdapat keberagaman leksikal dalam perbedaan fonologis dan leksikal dialek yang ada di Kabupaten Lamongan. (4) Penelitian yang dilakukan (Rahayu, 2012) berjudul Variasi Dialek Bahasa Jawa di Wilayah Kabupaten Ngawi: Kajian Dialektologi. Hasil penelitian menunjukkan bahwa variasi dialek bahasa Jawa ditemukan di wilayah Ngawi. Hal itu ditunjukkan melalui hasil deskripsi dalam bidang fonologi dan leksikal. Selain itu, penelitian ini menunjukkan bahwa dialek yang digunakan di wilayah Ngawi adalah dialek Jawa Tengah walaupun Ngawi termasuk wilayah yang ada di Provinsi Jawa Timur.

Dari beberapa penelitian di atas, penelitian ini berbeda dengan penelitian tersebut karena penelitian ini membandingkan dialek bahasa Jawa yang ada di wilayah yang berbatasan langsung, yaitu dialek bahasa Jawa yang ada di wilayah Malang dan dialek bahasa Jawa yang ada di wilayah Blitar. Penelitian ini akan mendeskripsikan bentuk leksikon yang memiliki bentuk dan makna yang sama, bentuk leksikon yang memiliki bentuk mirip dan makna yang sama, dan bentuk leksikon yang memiliki bentuk sama, tetapi maknanya berbeda pada bahasa Jawa dialek Malang dan bahasa Jawa dialek Blitar. Akan tetapi, jenis dan pendekatan yang digunakan dalam penelitian ini sama dengan jenis dan pendekatan pada penelitian sebelumnya, yaitu jenis penelitian deskriptif dan pendekatan kualitatif.

Dalam suatu bahasa, terutama bahasa Jawa, di beberapa tempat memiliki leksikon sendiri-sendiri. Hal itu dipengaruhi oleh beberapa sebab, misalnya pengaruh Kerajaan Mataram yang sampai di wilayah Blitar yang menyebabkan dialek bahasa Jawa yang digunakan di wilayah Blitar menggunakan dialek bahasa Jawa Solo-Yogya. Sementara wilayah Malang yang tidak mendapatkan pengaruh dari Kerajaan Mataram memiliki perbedaan dialek dengan wilayah Blitar walaupun berbatasan langsung. Leksikon adalah keragaman kata yang dimiliki seseorang atau suatu bahasa dalam hal pembendaharaan kata atau kosakata (Kridalaksana, 2013). Lebih lanjut, menurut Kridalaksana, leksikon dibagi dalam dua jenis, yaitu leksikon pasif dan leksikon aktif. Leksikon pasif adalah keragaman kata yang dimiliki seseorang, tetapi tidak pernah atau jarang digunakan. Sementara itu, leksikon aktif adalah keragaman kata yang biasa digunakan oleh seseorang.

Dialek dalam bahasa dibagi menjadi lima variasi, seperti pendapat Guiraud dalam (Ayatrohaedi, 1983) adalah sebagai berikut.

1. Perbedaan fonetik, polimorfisme, atau alofonik adalah perbedaan yang ada dalam bidang fonologi. Dalam hal ini pengguna dialek tidak menyadari adanya perbedaan dialek yang digunakan. Perbedaan fonetik tersebut dapat ditemukan pada vokal atau konsonan.

2. Perbedaan semantik adalah perbedaan yang mengacu pada terciptanya kata-kata baru berdasarkan perubahan fonologi dan pergeseran bentuk.

3. Perbedaan onomasiologis adalah perbedaan yang mengacu pada pemberian nama yang berbeda dalam satu konsep di beberapa tempat yang berbeda.

4. Perbedaan semasiologis adalah perbedaan yang mengacu pada pemberian nama yang sama dalam beberapa konsep yang berbeda.

5. Perbedaan morfologi adalah perbedaan yang dibatasi oleh adanya sistem tata bahasa yang berlaku, seperti frekuensi morfem-morfem yang berbeda, kegunaannya yang berkerabat, wujud fonetis, dan daya rasa. 
Lebih lanjut, Ayatrohaedi (1983) membagi dialek dalam tiga golongan, antara lain

1. Golongan 1, dalam kepustakaan dialektologi Roman dialek ini disebut dalecte, yaitu dialek yang berbeda-beda karena kondisi alam sekitar dialek tersebut dipakai selama perkembangannya. Dialek tersebut dihasilkan karena adanya dua faktor yang saling melengkapi, yaitu faktor tempat dan waktu.

2. Golongan 2, dalam kepustakaan dialektologi Roman dialek ini disebut dialecte, regiolecte, atau dialecte regional yang berarti bahasa yang dipakai di luar daerah penggunanya.

3. Golongan 3, dialek sosial atau sosiolacte adalah ragam bahasa yang dipakai oleh suatu kelompok masyarakat untuk membedakan dari kelompok masyarakat.

Kata merupakan satuan bahasa yang dapat berdiri sendiri, terjadi dari morfem tunggal (misalnya batu, rumah, datang) atau gabungan morfem (misalnya pejuang, pancasila, mahakuasa) (Kamus, 2016). Setiap kata memiliki makna leksikal. Kridalaksana (2013) menyatakan bahwa makna leksikal merupakan makna dalam unsur-unsur bahasa sebagai simbol benda, suatu kejadian, dan lain-lain. Kata leksikal merupakan adjektiva dari kata leksikon yang berarti maknanya berhubungan erat dimiliki oleh setiap leksem (satuan leksikon). Jadi, jika leksem disamakan dengan kata, leksikal disamakan dengan makna kata. Makna kata yang akan dibandingkan antara bahasa Jawa dialek Malang dan bahasa Jawa Dialek Blitar adalah makna leksikal, bukan frasa, klausa, atau kalimat.

\section{METODE PENELITIAN}

Metode penelitian yang digunakan dalam penelitian ini menggunakan jenis penelitian deskriptif dan pendekatan kualitatif. Menurut Zainuddin (Amar, 2010), penelitian deskriptif memiliki tujuan untuk memperoleh gambaran dan deskripsi secara terperinci, sistematis, dan akurat suatu kejadian. Sementara itu, Moleong (2007) mengatakan bahwa pendekatan kualitatif adalah pendekatan dalam penelitian yang bermaksud untuk memahami kejadian yang dialami oleh subjek penelitian secara menyeluruh dengan cara mendeskripsikan dalam kata-kata secara alami. Metode penelitian ini dipilih dengan pertimbangan bahwa penelitian ini mencoba mencatat dan mendeskripsikan data yang menjadi sasaran penelitian secara alamiah. Artinya, peneliti berusaha mencatat secara teliti data secara apa adanya dari wawancara secara daring responden dari Malang dan Blitar atau data yang terdapat dalam media sosial orang dari wilayah Malang dan orang dari wilayah Blitar.

Fokus kajian pada penelitian ini adalah perbandingan fonologis yang ada dalam leksikon bahasa Jawa Dialek Malang dan bahasa Jawa Dialek Blitar. Sumber data dalam penelitian ini adalah wawancara/bertanya langsung kepada responden dari Malang dan Blitar melalui Whatsapp mengenai kata-kata yang memiliki (l) bentuk yang berbeda, tetapi memiliki makna yang sama; (2) bentuk yang mirip dan makna yang sama; dan (3) bentuk yang sama, tetapi makna berbeda. Selain itu, peneliti juga dapat memperoleh data dari sumber tertulis berupa tulisan yang terdapat dalam media sosial orang dari wilayah Malang dan orang dari wilayah Blitar. Data dalam penelitian ini adalah keseluruhan kata yang diberikan oleh responden yang ditanya langsung oleh peneliti dan kata yang digunakan dalam media sosial orang dari wilayah Malang dan orang dari wilayah Blitar berupa bahasa Jawa dialek Malang dan bahasa Jawa dialek Blitar.

Teknik pengumpulan data menggunakan teknik wawancara, teknik baca, teknik dokumentasi, dan teknik catat. Langkah-langkah yang dilakukan dalam menganalisis data adalah sebagai berikut. Pertama, menentukan leksikon yang memiliki bentuk berbeda, tetapi maknanya sama pada bahasa Jawa dialek Malang (BJM) dan bahasa Jawa Dialek Blitar (BJB). Kedua, menentukan leksikon yang memiliki bentuk mirip dan makna yang sama pada bahasa Jawa dialek Malang (BJM) dan bahasa Jawa Dialek Blitar (BJB). Ketiga, menentukan leksikon yang memiliki bentuk sama, tetapi maknanya berbeda pada bahasa Jawa dialek Malang (BJM) dan bahasa Jawa Dialek Blitar (BJB). 


\section{PEMBAHASAN}

\section{Leksikon bentuk berbeda, tetapi maknanya sama}

Leksikon yang memiliki bentuk berbeda, tetapi memiliki makna yang sama ditemukan dalam bahasa Jawa dialek Malang dan bahasa Jawa dialek Blitar. Yang dimaksud leksikon yang memiliki bentuk berbeda adalah leksikon yang bentuk fonologis yang berbeda antara leksikon bahasa Jawa dialek Malang dan leksikon bahasa Jawa dialek Blitar. Walaupun memiliki bentuk fonologis yang berbeda, kedua leksikon tersebut memiliki makna yang sama.

\begin{tabular}{llll}
\hline No. & Leksikon Malang & Leksikon Blitar & Makna \\
\hline 1. & arek & bocah & anak \\
\hline 2. & iku & kuwi & itu \\
\hline 3. & lugur & ceblok & jatuh \\
\hline 4. & cik & ben & agar/biar \\
\hline 5. & gelek & kerep & sering \\
\hline 6. & koen & kowe & kamu \\
\hline 7. & mokong & mbeling & nakal \\
\hline 8. & mengong & cengoh & bodoh \\
\hline 9. & tutuk & tekan & sampai \\
\hline 10. & singitan & ndelik & bersembunyi \\
\hline 11. & goroh/mbujuk & Ngapusi & berbohong \\
\hline 12. & licik & Jirih & penakut \\
\hline 13. & nyelang & Nyilih & pinjam \\
\hline 14. & kate & Arep & akan \\
\hline 15. & nyacak & Njajal & mencoba \\
\hline 16. & yok opo & Piye & bagaimana \\
\hline 17. & opo o & Giniyo & kenapa \\
\hline 18. & ndik & Nek & di \\
\hline 19. & cowek & layah & cobek \\
\hline 20. & mene & sesok & besok \\
\hline 21. & geger & boyok & punggung \\
\hline 22. & kereng & elekan & jahat \\
\hline 23. & sebul & damoni & meniup \\
\hline 24. & jejek & saduk & tendang \\
\hline 25. & kecapi & pamah & kunyah \\
\hline
\end{tabular}

Pembahasan dari hasil penelitian di atas adalah sebagai berikut.

1. Berdasarkan tabel no. 1 di atas dapat dilihat bahwa pengertian leksikon arek [are?] pada bahasa Jawa dialek Malang dan leksikon bocah [bocah] pada bahasa Jawa dialek Blitar memiliki kesamaan makna dalam bahasa Indonesia, yaitu 'anak'. Antara leksikon arek [are?] dan bocah [bocah] memiliki bentuk secara fonologis yang berbeda.

2. Berdasarkan tabel no. 2 di atas dapat dilihat bahwa pengertian leksikon iku [iku] pada bahasa Jawa dialek Malang dan leksikon kuwi [kuwi] pada bahasa Jawa dialek Blitar memiliki kesamaan makna dalam bahasa Indonesia, yaitu 'itu'. Antara leksikon iku [iku] dan kuwi [kuwi] memiliki bentuk secara fonologis yang berbeda.

3. Berdasarkan tabel no. 3 di atas dapat dilihat bahwa pengertian leksikon lugur [lUgUr] pada bahasa Jawa dialek Malang dan leksikon ceblok [cəblo?] pada bahasa Jawa dialek Blitar memiliki kesamaan makna dalam bahasa Indonesia, yaitu 'jatuh'. Antara leksikon lugur [lUgUr] dan ceblok [cablo?] memiliki bentuk secara fonologis yang berbeda.

4. Berdasarkan tabel no. 4 di atas dapat dilihat bahwa pengertian leksikon cik [cI?] pada bahasa Jawa dialek Malang dan leksikon ben [ben] pada bahasa Jawa dialek 
Blitar memiliki kesamaan makna dalam bahasa Indonesia, yaitu 'agar' atau 'biar' . Antara leksikon cik [cl?] dan ben [ben] memiliki bentuk secara fonologis yang berbeda.

5. Berdasarkan tabel no. 5 di atas dapat dilihat bahwa pengertian leksikon gelek [gələ?] pada bahasa Jawa dialek Malang dan leksikon kerep [kərəp] pada bahasa Jawa dialek Blitar memiliki kesamaan makna dalam bahasa Indonesia, yaitu 'sering'. Antara leksikon gelek [gələ?] dan kerep [kərəp] memiliki bentuk secara fonologis yang berbeda.

6. Berdasarkan tabel no. 6 di atas dapat dilihat bahwa pengertian leksikon koen [kəən] pada bahasa Jawa dialek Malang dan leksikon kowe [kUwe] pada bahasa Jawa dialek Blitar memiliki kesamaan makna dalam bahasa Indonesia, yaitu 'kamu'. Antara leksikon koen [kכən] dan kowe [kUwe] memiliki bentuk secara fonologis yang berbeda.

7. Berdasarkan tabel no. 7 di atas dapat dilihat bahwa pengertian leksikon mokong [mokon] pada bahasa Jawa dialek Malang dan leksikon mbeling [mbəlin] pada bahasa Jawa dialek Blitar memiliki kesamaan makna dalam bahasa Indonesia, yaitu 'nakal'. Antara leksikon mokong [mokon] dan mbeling [mbəlin] memiliki bentuk secara fonologis yang berbeda.

8. Berdasarkan tabel no. 8 di atas dapat dilihat bahwa pengertian leksikon mengong [meyəy] pada bahasa Jawa dialek Malang dan leksikon cengoh [cəyəh] pada bahasa Jawa dialek Blitar memiliki kesamaan makna dalam bahasa Indonesia, yaitu 'bodoh'. Antara leksikon mengong [meyəy] dan cengoh [cəyəh] memiliki bentuk secara fonologis yang berbeda.

9. Berdasarkan tabel no. 9 di atas dapat dilihat bahwa pengertian leksikon tutuk [tUtU?] pada bahasa Jawa dialek Malang dan leksikon tekan [təkan] pada bahasa Jawa dialek Blitar memiliki kesamaan makna dalam bahasa Indonesia, yaitu 'sampai'. Antara leksikon tutuk [tUtU?] dan tekan [təkan] memiliki bentuk secara fonologis yang berbeda.

10. Berdasarkan tabel no. 10 di atas dapat dilihat bahwa pengertian leksikon tutuk [tUtU?] pada bahasa Jawa dialek Malang dan leksikon tekan [təkan] pada bahasa Jawa dialek Blitar memiliki kesamaan makna dalam bahasa Indonesia, yaitu 'bersembunyi'. Antara leksikon tutuk [tUtU?] dan tekan [təkan] memiliki bentuk secara fonologis yang berbeda.

11. Berdasarkan tabel no. Il di atas dapat dilihat bahwa pengertian leksikon goroh/mbujuk [goroh]/[mbUjU?] pada bahasa Jawa dialek Malang dan leksikon ngapusi [yapusi] pada bahasa Jawa dialek Blitar memiliki kesamaan makna dalam bahasa Indonesia, yaitu 'berbohong'. Antara leksikon goroh/mbujuk [goroh]/[mbUjU?] dan ngapusi [yapusi] memiliki bentuk secara fonologis yang berbeda.

12. Berdasarkan tabel no. 12 di atas dapat dilihat bahwa pengertian leksikon licik [IIcI?] pada bahasa Jawa dialek Malang dan leksikon jirih [jirIh] pada bahasa Jawa dialek Blitar memiliki kesamaan makna dalam bahasa Indonesia, yaitu 'penakut'. Antara leksikon licik [IIcI?] dan jirih [jirIh] memiliki bentuk secara fonologis yang berbeda.

13. Berdasarkan tabel no. 13 di atas dapat dilihat bahwa pengertian leksikon nyelang [ñəlay] pada bahasa Jawa dialek Malang dan leksikon nyilih [ñillh] pada bahasa Jawa dialek Blitar memiliki kesamaan makna dalam bahasa Indonesia, yaitu 'pinjam'. Antara leksikon nyelang [ñolan] dan nyilih [ñillh] memiliki bentuk secara fonologis yang berbeda.

14. Berdasarkan tabel no. 14 di atas dapat dilihat bahwa pengertian leksikon kate [kate] pada bahasa Jawa dialek Malang dan leksikon arep [arəp] pada bahasa Jawa dialek Blitar memiliki kesamaan makna dalam bahasa Indonesia, yaitu 'akan'. Antara leksikon kate [kate] dan arep [arəp] memiliki bentuk secara fonologis yang berbeda.

15. Berdasarkan tabel no. 15 di atas dapat dilihat bahwa pengertian leksikon nyacak [ñaca?] pada bahasa Jawa dialek Malang dan leksikon njajal [njajal] pada bahasa 
Jawa dialek Blitar memiliki kesamaan makna dalam bahasa Indonesia, yaitu 'mencoba'. Antara leksikon nyacak [ñaca?] dan njajal [njajal] memiliki bentuk secara fonologis yang berbeda.

16. Berdasarkan tabel no. 16 di atas dapat dilihat bahwa pengertian leksikon yok opo [yэ? эрэ] pada bahasa Jawa dialek Malang dan leksikon piye [piye] pada bahasa Jawa dialek Blitar memiliki kesamaan makna dalam bahasa Indonesia, yaitu 'bagaimana'. Antara leksikon yok opo [yэ? эрэ] dan piye [piye] memiliki bentuk secara fonologis yang berbeda.

17. Berdasarkan tabel no. 17 di atas dapat dilihat bahwa pengertian leksikon opo o [jpo? э] pada bahasa Jawa dialek Malang dan leksikon giniyo [giniyə] pada bahasa Jawa dialek Blitar memiliki kesamaan makna dalam bahasa Indonesia, yaitu 'kenapa'. Antara leksikon opo o [эрэ? כ] dan giniyo [giniys] memiliki bentuk secara fonologis yang berbeda.

18. Berdasarkan tabel no. 18 di atas dapat dilihat bahwa pengertian leksikon ndik [ndI?] pada bahasa Jawa dialek Malang dan leksikon nek [ne?] pada bahasa Jawa dialek Blitar memiliki kesamaan makna dalam bahasa Indonesia, yaitu 'di (kata depan)'. Antara leksikon ndik [ndI?] dan nek [ne?] memiliki bentuk secara fonologis yang berbeda.

19. Berdasarkan tabel no. 19 di atas dapat dilihat bahwa pengertian leksikon cowek [cэwe?] pada bahasa Jawa dialek Malang dan leksikon layah [layah] pada bahasa Jawa dialek Blitar memiliki kesamaan makna dalam bahasa Indonesia, yaitu 'cobek'. Antara leksikon cowek [cכwe?] dan layah [layah] memiliki bentuk secara fonologis yang berbeda.

20. Berdasarkan tabel no. 20 di atas dapat dilihat bahwa pengertian leksikon mene [məne] pada bahasa Jawa dialek Malang dan leksikon sesuk [sesU?] pada bahasa Jawa dialek Blitar memiliki kesamaan makna dalam bahasa Indonesia, yaitu 'besok'. Antara leksikon mene [məne] dan sesuk [sesU?] memiliki bentuk secara fonologis yang berbeda.

21. Berdasarkan tabel no. 21 di atas dapat dilihat bahwa pengertian leksikon geger [gəgər] pada bahasa Jawa dialek Malang dan leksikon boyok [bəyว?] pada bahasa Jawa dialek Blitar memiliki kesamaan makna dalam bahasa Indonesia, yaitu 'punggung'. Antara leksikon geger [gəgər] dan boyok [bəyэ?] memiliki bentuk secara fonologis yang berbeda.

22. Berdasarkan tabel no. 22 di atas dapat dilihat bahwa pengertian leksikon kereng [kərəy] pada bahasa Jawa dialek Malang dan leksikon elekan [عle?an] pada bahasa Jawa dialek Blitar memiliki kesamaan makna dalam bahasa Indonesia, yaitu 'jahat'. Antara leksikon kereng [kərəy] dan elekan [عle?an] memiliki bentuk secara fonologis yang berbeda.

23. Berdasarkan tabel no. 23 di atas dapat dilihat bahwa pengertian leksikon sebul [səbUl] pada bahasa Jawa dialek Malang dan leksikon damoni [damoni] pada bahasa Jawa dialek Blitar memiliki kesamaan makna dalam bahasa Indonesia, yaitu 'meniup'. Antara leksikon sebul [səbUl] dan damoni [damoni] memiliki bentuk secara fonologis yang berbeda.

24. Berdasarkan tabel no. 24 di atas dapat dilihat bahwa pengertian leksikon jejek [jəjə?] pada bahasa Jawa dialek Malang dan leksikon saduk [sadU?] pada bahasa Jawa dialek Blitar memiliki kesamaan makna dalam bahasa Indonesia, yaitu 'tendang'. Antara leksikon jejek [jəjə?] dan saduk [sadU?] memiliki bentuk secara fonologis yang berbeda.

25. Berdasarkan tabel no. 24 di atas dapat dilihat bahwa pengertian leksikon kecapi [kəcapi] pada bahasa Jawa dialek Malang dan leksikon pamah [pamah] pada bahasa Jawa dialek Blitar memiliki kesamaan makna dalam bahasa Indonesia, yaitu 'kunyah'. Antara leksikon kecapi [kəcapi] dan pamah [pamah] memiliki bentuk secara fonologis yang berbeda. 


\section{Leksikon bentuk mirip dan makna yang sama}

Leksikon yang memiliki bentuk mirip dan memiliki makna yang sama ditemukan dalam bahasa Jawa dialek Malang dan bahasa Jawa dialek Blitar. Yang dimaksud leksikon yang memiliki bentuk mirip adalah leksikon yang memiliki perbedaan pelafalan satu atau dua huruf fonologisnya antara leksikon bahasa Jawa dialek Malang dan leksikon bahasa Jawa dialek Blitar. Leksikon yang berbentuk mirip adalah kosakata yang memiliki perbedaan pada satu atau dua bunyi dengan posisi yang sama, tetapi maknanya sama (Mahsun, 2009).

\begin{tabular}{|c|c|c|c|}
\hline No. & Leksikon Malang & Leksikon Blitar & Makna \\
\hline 1. & pitik [pItI?] & pitik [pitI?] & Ayam \\
\hline 2. & irung [IrUn] & irung [irUy] & Hidung \\
\hline 3. & itung [ItUn] & itung [itUy] & Hitung \\
\hline 4. & sikil[sIkIl] & sikil[sikIl] & Kaki \\
\hline 5. & krikil [krIkIl] & krikil [krikIl] & Kerikil \\
\hline 6. & sugih [sUgIh] & sugih [sugIh] & Kaya \\
\hline 7. & krupuk [krUpU?] & krupuk [krupU?] & Kerupuk \\
\hline 8. & engkok [ə⿹kko?] & engko [əクko] & Nantí \\
\hline 9. & mulih [mUlih] & mulih [mulIh] & Pulang \\
\hline 10. & onok [ono?] & enek [عne?] & Ada \\
\hline 11. & demok [dəmo?] & demek [dəmє?] & Pegang \\
\hline 12. & anyar [añar] & enyar [əñar] & Baru \\
\hline 13. & belung [balUy] & balung [balUn] & Tulang \\
\hline 14. & ngilokno [yilo?no] & ngelokno [yalo?no] & Menghina \\
\hline 15. & ambe'an [ambo?an] & ambekan [ambəkan] & Bernafas \\
\hline 16. & guwak [guwa?] & buwak [buwa?] & Buang \\
\hline 17. & gurung [gUrUy] & durung [durUy] & Belum \\
\hline 18. & setriko [satriko] & setliko [satlikJ] & Setrika \\
\hline 19. & jukuk [jUkU?] & jupuk [jupU?] & Ambil \\
\hline 20. & ulu [ulu] & wulu [wulu] & Bulu \\
\hline 21. & bener [bənər] & pener [ponər] & Benar \\
\hline 22. & idek [idə?] & pidek [pidə?] & Injak \\
\hline
\end{tabular}

Pembahasan dari hasil penelitian di atas adalah sebagai berikut.

1. Berdasarkan tabel no. 1 di atas dapat dilihat bahwa leksikon pitik [pItI?] pada bahasa Jawa dialek Malang dan leksikon pitik [pitI?] pada bahasa Jawa dialek Blitar yang bermakna 'ayam' memiliki memiliki kemiripan bentuk fonologis. Perbedaannya ada pada pelafalan suku kata pertama, yaitu pelafalan [pI] di dialek Malang dan [pi] di dialek Blitar.

2. Berdasarkan tabel no. 2 di atas dapat dilihat bahwa leksikon irung [IrUn] pada bahasa Jawa dialek Malang dan leksikon irung [irUn] pada bahasa Jawa dialek Blitar yang bermakna 'hidung' memiliki memiliki kemiripan bentuk fonologis. Perbedaannya ada pada pelafalan vokal suku kata pertama, yaitu pelafalan [I] di dialek Malang dan [i] di dialek Blitar.

3. Berdasarkan tabel no. 3 di atas dapat dilihat bahwa leksikon itung [ItUn] pada bahasa Jawa dialek Malang dan leksikon itung [itUn] pada bahasa Jawa dialek Blitar yang bermakna 'hitung' memiliki memiliki kemiripan bentuk fonologis. Perbedaannya ada pada pelafalan vokal suku kata pertama, yaitu pelafalan [I] di dialek Malang dan [i] di dialek Blitar.

4. Berdasarkan tabel no. 4 di atas dapat dilihat bahwa leksikon sikil [sIkIl] pada bahasa Jawa dialek Malang dan leksikon sikil [sikIl] pada bahasa Jawa dialek Blitar yang bermakna 'kaki' memiliki memiliki kemiripan bentuk fonologis. Perbedaannya ada 
pada pelafalan suku kata pertama, yaitu pelafalan [sI] di dialek Malang dan [si] di dialek Blitar.

5. Berdasarkan tabel no. 5 di atas dapat dilihat bahwa leksikon krikil [krIkIl] pada bahasa Jawa dialek Malang dan leksikon krikil [krikIl] pada bahasa Jawa dialek Blitar yang bermakna 'kerikil' memiliki memiliki kemiripan bentuk fonologis. Perbedaannya ada pada pelafalan suku kata pertama, yaitu pelafalan [krI] di dialek Malang dan [kri] di dialek Blitar.

6. Berdasarkan tabel no. 6 di atas dapat dilihat bahwa leksikon sugih [sUgIh] pada bahasa Jawa dialek Malang dan leksikon sugih [sugIh] pada bahasa Jawa dialek Blitar yang bermakna 'kaya' memiliki memiliki kemiripan bentuk fonologis. Perbedaannya ada pada pelafalan suku kata pertama, yaitu pelafalan [sU] di dialek Malang dan [su] di dialek Blitar.

7. Berdasarkan tabel no. 7 di atas dapat dilihat bahwa leksikon krupuk [krUpU?] pada bahasa Jawa dialek Malang dan leksikon krupuk [krupU?] pada bahasa Jawa dialek Blitar yang bermakna 'kerupuk' memiliki memiliki kemiripan bentuk fonologis. Perbedaannya ada pada pelafalan suku kata pertama, yaitu pelafalan [krU] di dialek Malang dan [kru] di dialek Blitar.

8. Berdasarkan tabel no. 8 di atas dapat dilihat bahwa leksikon engkok [ənko?] pada bahasa Jawa dialek Malang dan leksikon engko [əyko] pada bahasa Jawa dialek Blitar yang bermakna 'nanti' memiliki memiliki kemiripan bentuk fonologis. Perbedaannya ada pada pelafalan akhiran suku kata terakhir, yaitu disertai bunyi [?] sebagai penutup suku kata terakhir di dialek Malang dan tetap terbuka tanpa bunyi [?] sebagai penutup suku kata terakhir di dialek Blitar.

9. Berdasarkan tabel no. 9 di atas dapat dilihat bahwa leksikon mulih [mUlIh] pada bahasa Jawa dialek Malang dan leksikon mulih [mullh] pada bahasa Jawa dialek Blitar yang bermakna 'pulang' memiliki memiliki kemiripan bentuk fonologis. Perbedaannya ada pada pelafalan suku kata pertama, yaitu pelafalan [mU] di dialek Malang dan [mu] di dialek Blitar.

10. Berdasarkan tabel no. 10 di atas dapat dilihat bahwa leksikon onok [on॰?] pada bahasa Jawa dialek Malang dan leksikon enek [ene?] pada bahasa Jawa dialek Blitar yang bermakna 'ada' memiliki memiliki kemiripan bentuk fonologis. Perbedaannya ada pada pelafalan huruf vokal yang ada di dalam kata tersebut, yaitu pelafalan [o] di dialek Malang dan $[\varepsilon]$ di dialek Blitar.

11. Berdasarkan tabel no. 11 di atas dapat dilihat bahwa leksikon demok [dəmo?] pada bahasa Jawa dialek Malang dan leksikon demek [dəme?] pada bahasa Jawa dialek Blitar yang bermakna 'pegang' memiliki memiliki kemiripan bentuk fonologis. Perbedaannya ada pada pelafalan suku kata terakhir, yaitu pelafalan [mo?] di dialek Malang dan [me?] di dialek Blitar.

12. Berdasarkan tabel no. 12 di atas dapat dilihat bahwa leksikon anyar [añar] pada bahasa Jawa dialek Malang dan leksikon enyar [əñar] pada bahasa Jawa dialek Blitar yang bermakna 'baru' memiliki memiliki kemiripan bentuk fonologis. Perbedaannya ada pada pelafalan suku kata pertama, yaitu pelafalan [a] di dialek Malang dan [ə] di dialek Blitar.

13. Berdasarkan tabel no. 13 di atas dapat dilihat bahwa leksikon belung [bəlUn] pada bahasa Jawa dialek Malang dan leksikon balung [balUn] pada bahasa Jawa dialek Blitar yang bermakna 'tulang' memiliki memiliki kemiripan bentuk fonologis. Perbedaannya ada pada pelafalan suku kata pertama, yaitu pelafalan [bə] di dialek Malang dan [ba] di dialek Blitar.

14. Berdasarkan tabel no. 14 di atas dapat dilihat bahwa leksikon ngilokno [yilo?no] pada bahasa Jawa dialek Malang dan leksikon ngelokno [yəlo?no] pada bahasa Jawa dialek Blitar yang bermakna 'menghina' memiliki memiliki kemiripan bentuk fonologis. Perbedaannya ada pada pelafalan suku kata pertama, yaitu pelafalan [ni] di dialek Malang dan [yə] di dialek Blitar. 
15. Berdasarkan tabel no. 15 di atas dapat dilihat bahwa leksikon ambe'an [ambə?an] pada bahasa Jawa dialek Malang dan leksikon ambekan [ambəkan] pada bahasa Jawa dialek Blitar yang bermakna 'bernafas' memiliki memiliki kemiripan bentuk fonologis. Perbedaannya ada pada pelafalan suku kata terakhir, yaitu pelafalan [?an] di dialek Malang dan [kan] di dialek Blitar.

16. Berdasarkan tabel no. 16 di atas dapat dilihat bahwa leksikon guwak [guwa?] pada bahasa Jawa dialek Malang dan leksikon buwak [buwa?] pada bahasa Jawa dialek Blitar yang bermakna 'buang' memiliki memiliki kemiripan bentuk fonologis. Perbedaannya ada pada pelafalan suku kata pertama, yaitu pelafalan [gu] di dialek Malang dan [bu] di dialek Blitar.

17. Berdasarkan tabel no. 17 di atas dapat dilihat bahwa leksikon gurung [gUrUn] pada bahasa Jawa dialek Malang dan leksikon durung [durUy] pada bahasa Jawa dialek Blitar yang bermakna 'belum' memiliki memiliki kemiripan bentuk fonologis. Perbedaannya ada pada pelafalan suku kata pertama, yaitu pelafalan [gU] di dialek Malang dan [du] di dialek Blitar.

18. Berdasarkan tabel no. 18 di atas dapat dilihat bahwa leksikon setriko [sətrikə] pada bahasa Jawa dialek Malang dan leksikon setliko [sətlikə] pada bahasa Jawa dialek Blitar yang bermakna 'setrika' memiliki memiliki kemiripan bentuk fonologis. Perbedaannya ada pada pelafalan suku kata kedua, yaitu pelafalan [tri] di dialek Malang dan [tli] di dialek Blitar.

19. Berdasarkan tabel no. 19 di atas dapat dilihat bahwa leksikon jukuk [jUkU?] pada bahasa Jawa dialek Malang dan leksikon jupuk [jupU?] pada bahasa Jawa dialek Blitar yang bermakna 'ambil' memiliki memiliki kemiripan bentuk fonologis. Perbedaannya ada pada pelafalan suku kata terakhir, yaitu pelafalan [kU?] di dialek Malang dan [pU?] di dialek Blitar.

20. Berdasarkan tabel no. 20 di atas dapat dilihat bahwa leksikon ulu [ulu] pada bahasa Jawa dialek Malang dan leksikon wulu [wulu] pada bahasa Jawa dialek Blitar yang bermakna 'bulu' memiliki memiliki kemiripan bentuk fonologis. Perbedaannya ada pada pelafalan suku kata pertama, yaitu pelafalan [u] di dialek Malang dan [wu] di dialek Blitar.

21. Berdasarkan tabel no. 21 di atas dapat dilihat bahwa leksikon bener [bənər] pada bahasa Jawa dialek Malang dan leksikon pener [pənər] pada bahasa Jawa dialek Blitar yang bermakna 'benar' memiliki memiliki kemiripan bentuk fonologis. Perbedaannya ada pada pelafalan suku kata pertama, yaitu pelafalan [bə] di dialek Malang dan [po] di dialek Blitar.

22. Berdasarkan tabel no. 22 di atas dapat dilihat bahwa leksikon idek [idə?] pada bahasa Jawa dialek Malang dan leksikon pidek [pidə?] pada bahasa Jawa dialek Blitar yang bermakna 'benar' memiliki memiliki kemiripan bentuk fonologis. Perbedaannya ada pada pelafalan suku kata pertama, yaitu pelafalan [i] di dialek Malang dan [pi] di dialek Blitar.

\section{Leksikon bentuk sama, tetapi maknanya berbeda}

Leksikon yang memiliki bentuk sama, tetapi memiliki makna yang berbeda ditemukan dalam bahasa Jawa dialek Malang dan bahasa Jawa dialek Blitar. Yang dimaksud leksikon yang memiliki bentuk sama adalah leksikon yang bentuk fonologis (pelafalan dan penulisan) sama antara leksikon bahasa Jawa dialek Malang dan leksikon bahasa Jawa dialek Blitar. Walaupun memiliki bentuk fonologis yang sama, kedua leksikon tersebut memiliki makna yang berbeda.

\begin{tabular}{llll}
\hline No. & Leksikon & Makna di Malang & Makna di Blitar \\
\hline 1. & balon [balon] & PSK & balon \\
\hline 2. & iwak [iwa?] & lauk & ikan \\
\hline 3. & embong [embon] & jalan & bantaran sungai \\
\hline 4. & ndorong [ndhoron] & memukul/mendorong & duduk santai \\
\hline
\end{tabular}




\begin{tabular}{llll}
\hline 5. & ote-ote [ote-ote] & telanjang dada & bakwan \\
\hline 6. & mari [mari] & selesai & sembuh \\
\hline 7. & nggawe [ygawe] & memakai & membuat \\
\hline 8. & waras [waras] & sehat secara jasmani & sehat secara psikologis \\
\hline 9. & montor [montor] & mobil & sepeda motor \\
\hline 10. & katok [kato?] & celana pendek & celana secara umum \\
\hline 11. & teko [təkว] & dari & datang/sampai \\
\hline 12. & tepak [təpa?] & pas/cocok & Jejak \\
\hline 13. & kate [kate] & akan & ayam kate \\
\hline 14. & antem [antəm] & memukul & melempar \\
\hline 15. & gering [gərIn] & sakit & Kurus \\
\hline 16. & telo [tzlo] & ketela rambat & ketela pohon \\
\hline
\end{tabular}

Pembahasan dari hasil penelitian di atas adalah sebagai berikut.

1. Berdasarkan tabel no. 1 di atas dapat dilihat bahwa leksikon balon [balon] pada bahasa Jawa dialek Malang bisa memiliki makna 'PSK' dan pada bahasa Jawa dialek Blitar memiliki makna 'balon' (bola atau pundi-pundi besar dibuat dari karet [kertas, kain, dan sebagainya] yang diisi udara [gas yang ringan]). Dengan demikian, leksikon balon [balon] di Malang dan di Blitar bisa memiliki makna yang berbeda walaupun bentuk fonologisnya sama.

2. Berdasarkan tabel no. 2 di atas dapat dilihat bahwa leksikon iwak [iwa?] pada bahasa Jawa dialek Malang bisa memiliki makna 'lauk' dan pada bahasa Jawa dialek Blitar memiliki makna 'ikan'. Dengan demikian, leksikon iwak [iwa?] di Malang dan di Blitar bisa memiliki makna yang berbeda walaupun bentuk fonologisnya sama.

3. Berdasarkan tabel no. 3 di atas dapat dilihat bahwa leksikon embong [عmbon] pada bahasa Jawa dialek Malang memiliki makna 'jalan' dan pada bahasa Jawa dialek Blitar memiliki makna 'bantaran sungai'. Dengan demikian, leksikon embong [عmbəy] di Malang dan di Blitar memiliki makna yang berbeda walaupun bentuk fonologisnya sama.

4. Berdasarkan tabel no. 4 di atas dapat dilihat bahwa leksikon ndorong [ndhoroy] pada bahasa Jawa dialek Malang memiliki makna 'memukul/mendorong' dan pada bahasa Jawa dialek Blitar memiliki makna 'duduk santai'. Dengan demikian, leksikon ndorong [ndhoron] di Malang dan di Blitar memiliki makna yang berbeda walaupun bentuk fonologisnya sama.

5. Berdasarkan tabel no. 5 di atas dapat dilihat bahwa leksikon ote-ote [ote-ote] pada bahasa Jawa dialek Malang memiliki makna 'telanjang dada' dan pada bahasa Jawa dialek Blitar memiliki makna 'bakwan'. Dengan demikian, leksikon ote-ote [ote-ote] di Malang dan di Blitar memiliki makna yang berbeda walaupun bentuk fonologisnya sama.

6. Berdasarkan tabel no. 6 di atas dapat dilihat bahwa leksikon mari [mari] pada bahasa Jawa dialek Malang memiliki makna 'selesai' dan pada bahasa Jawa dialek Blitar memiliki makna ‘sembuh'. Dengan demikian, leksikon mari [mari] di Malang dan di Blitar memiliki makna yang berbeda walaupun bentuk fonologisnya sama.

7. Berdasarkan tabel no. 7 di atas dapat dilihat bahwa leksikon nggawe [ygawe] pada bahasa Jawa dialek Malang memiliki makna 'memakai' dan pada bahasa Jawa dialek Blitar memiliki makna 'membuat'. Dengan demikian, leksikon nggawe [ngawe] di Malang dan di Blitar memiliki makna yang berbeda walaupun bentuk fonologisnya sama.

8. Berdasarkan tabel no. 8 di atas dapat dilihat bahwa leksikon waras [waras] pada bahasa Jawa dialek Malang memiliki makna 'sehat secara jasmani' dan pada bahasa Jawa dialek Blitar memiliki makna 'sehat secara psikologis'. Dengan demikian, leksikon waras [waras] di Malang dan di Blitar memiliki makna yang berbeda walaupun bentuk fonologisnya sama. 
9. Berdasarkan tabel no. 9 di atas dapat dilihat bahwa leksikon montor [montor] pada bahasa Jawa dialek Malang memiliki makna 'mobil' dan pada bahasa Jawa dialek Blitar memiliki makna 'sepeda motor'. Dengan demikian, leksikon montor [montor] di Malang dan di Blitar memiliki makna yang berbeda walaupun bentuk fonologisnya sama.

10. Berdasarkan tabel no. 10 di atas dapat dilihat bahwa leksikon katok [kat’?] pada bahasa Jawa dialek Malang memiliki makna 'celana pendek' dan pada bahasa Jawa dialek Blitar memiliki makna 'celana secara umum'. Dengan demikian, leksikon katok [kato?] di Malang dan di Blitar memiliki makna yang berbeda walaupun bentuk fonologisnya sama.

11. Berdasarkan tabel no. 11 di atas dapat dilihat bahwa leksikon teko [təko] pada bahasa Jawa dialek Malang memiliki makna ‘dari' dan pada bahasa Jawa dialek Blitar memiliki makna 'datang/sampai'. Dengan demikian, leksikon teko [təko] di Malang dan di Blitar memiliki makna yang berbeda walaupun bentuk fonologisnya sama.

12. Berdasarkan tabel no. 12 di atas dapat dilihat bahwa leksikon tepak [təpa?] pada bahasa Jawa dialek Malang memiliki makna 'pas/cocok' dan pada bahasa Jawa dialek Blitar memiliki makna 'jejak'. Dengan demikian, leksikon tepak [təpa?] di Malang dan di Blitar memiliki makna yang berbeda walaupun bentuk fonologisnya sama.

13. Berdasarkan tabel no. 13 di atas dapat dilihat bahwa leksikon kate [kate] pada bahasa Jawa dialek Malang memiliki makna 'akan' dan pada bahasa Jawa dialek Blitar memiliki makna 'nama ayam kecil (ayam kate)'. Dengan demikian, leksikon kate [kate] di Malang dan di Blitar memiliki makna yang berbeda walaupun bentuk fonologisnya sama.

14. Berdasarkan tabel no. 14 di atas dapat dilihat bahwa leksikon antem [antəm] pada bahasa Jawa dialek Malang memiliki makna 'memukul' dan pada bahasa Jawa dialek Blitar memiliki makna 'melempar'. Dengan demikian, leksikon antem [antəm] di Malang dan di Blitar memiliki makna yang berbeda walaupun bentuk fonologisnya sama.

15. Berdasarkan tabel no. 15 di atas dapat dilihat bahwa leksikon gering [gərIn] pada bahasa Jawa dialek Malang memiliki makna 'sakit' dan pada bahasa Jawa dialek Blitar memiliki makna 'kurus'. Dengan demikian, leksikon gering [gərIn] di Malang dan di Blitar memiliki makna yang berbeda walaupun bentuk fonologisnya sama.

16. Berdasarkan tabel no. 16 di atas dapat dilihat bahwa leksikon telo [telo] pada bahasa Jawa dialek Malang memiliki makna 'ketela rambat' dan pada bahasa Jawa dialek Blitar memiliki makna 'ketela pohon'. Dengan demikian, leksikon gering [gərIn] di Malang dan di Blitar memiliki makna yang berbeda walaupun bentuk fonologisnya sama.

\section{PENUTUP}

Berdasarkan hasil dan pembahasan penelitian ini, simpulan perbandingan leksikon bahasa Jawa dialek Malang dan bahasa Jawa dialek Blitar adalah sebagai berikut.

Leksikon yang memiliki bentuk berbeda, tetapi maknanya sama pada bahasa Jawa dialek Malang (BJM) dan bahasa Jawa Dialek Blitar (BJB) banyak ditemukan dalam penelitian ini. Perbedaan leksikon pada BJM dan BJB ini ada pada tataran bahasa ngoko, sedangkan pada bahasa kromo inggil BJM dan BJB memiliki bentuk yang sama.

Leksikon yang memiliki bentuk mirip dan makna yang sama banyak ditemukan pada bahasa Jawa dialek Malang (BJM) dan bahasa Jawa Dialek Blitar (BJB). Perbedaan kata paling sering ditemukan pada BJM dan BJB adalah terletak pada huruf vokal pertama, terakhir, atau semua huruf vokal. Selain itu, ada pula perbedaannya pada konsonan walaupun hanya beberapa kata saja.

Leksikon yang memiliki bentuk sama, tetapi maknanya berbeda pada bahasa Jawa dialek Malang (BJM) dan bahasa Jawa Dialek Blitar (BJB) ditemukan paling sedikit pada penelitian ini. Kebanyakan yang ditemukan oleh peneliti adalah bentuk sama dan makna 
sama/ bentuk mirip dan makna sama. Hal itu memang jelas terjadi karena penelitian ini mengkaji bahasa Jawa di lingkup wilayah Malang dan Blitar. Namun, peneliti selanjutnya dapat mengembangkan metode penelitiannya agar kata-kata yang sama, tetapi memiliki makna yang berbeda lebih banyak ditemukan.

\section{DAFTAR PUSTAKA}

Adha, Y. R. (2011). Bahasa Jawa Dialek Gresik di Kabupaten Gresik Kajian Morfofonemik. Universitas Airlangga.

Afandi, M. I. (2010). Perbandingan Leksikon Bahasa Jawa Cirebon dengan Bahasa Jawa Standar. Universitas Negeri Semarang.

Amar, N. (2010). Praanggapan dan Implikatur pada Wacana Lisan dalam Acara Mata Najwa di Metro TV. Madah, 1, No. 1, 49-60.

Ayatrohaedi. (1983). Dialektologi: Sebuah Pengantar. Pusat Pembinaan dan Pengembangan Bahasa, Departemen Pendidikan dan Kebudayaan.

Ayatrohaedi. (2002). Dialektologi: Sebuah pengantar. Pusat Pembinaan dan Pengembangan Bahasa. Departemen Pendidikan dan Kebudayaan.

Bahasa dan Peta Bahasa di Indonesia. (2019). Badan Pengembangan Dan Pembinaan Bahasa. https://petabahasa.kemdikbud.go.id/index.php

Bahasa Jawa Provinsi Jawa Timur. (n.d.). Badan Pengembangan Dan Pembinaan Bahasa, Kementerian Pendidikan Dan Kebudayaan. Retrieved August 5, 2021, from https://petabahasa.kemdikbud.go.id/infobahasa2.php?idb=61\&eidp=Jawa Timur

Kamus. (2016). KBBI Daring. https://kbbi.kemdikbud.go.id/

Kridalaksana, H. (2013). Kamus Linguistik Umum (Keempat). Gramedia Pustaka Utama.

Mahsun. (2009). Pedoman Penelitian Dialektologi. Pusat Pembinaan dan Pengembangan Bahasa, Departemen Pendidikan dan Kebudayaan.

Moleong, J. L. (2007). Metodologi Penelitian Kualitatif. PT Remaja Rosdakarya.

Rahayu, I. (2012). Variasi Dialek Bahasa Jawa di Wilayah Kabupaten Ngawi: Kajian ialektologi. Universitas Airlangga.

Widayani, R. (2015). Variasi Dialek Bahasa Jawa di Wilayah Kabupaten Lamongan: Kajian Dialek Geografis. Universitas Airlangga.

Widjono, H. (2007). Bahasa Indonesia Mata Kuliah Pengembangan Kepribadian di Perguruan Tinggi (II). Grasindo.

Zulaeha. (2010). DIALEKTOLOGI Dialek Geografi dan Dialek Sosial (I). Graha Ilmu. 